\title{
General disaster preparedness beliefs and related sociodemographic characteristics: The example of Yalova University, Turkey
}

\author{
Ebru Inala, K. Hakan Altintas ${ }^{b}$, Nuri Doganc \\ aDr., Lecturer, Emergency and Disaster Management Onsekiz Mart University, Çanakkale, Turkey \\ bProf.Dr., Public Health Department of Public Health, Head, Faculty of Medicine, Hacettepe University, \\ Ankara, Turkey \\ cProf.Dr., Department of Educational Sciences of Faculty of Education, Hacettepe University, Ankara, \\ Turkey
}

Received: 19.01.2018, Accepted: 13.09.2018

\begin{abstract}
Aim: This study aimed to identify sociodemographic and disaster related factors associated with General Disaster Preparedness Belief using the Health Belief Model as a theoretical framework. Methods: The survey study was conducted in Yalova, Turkey between April and July, 2014. A prevalidated General Disaster Preparedness Belief scale instrument based on the Health Belief Model was administered to a study group of 286 academic and administrative staff. The General Disaster Preparedness Belief score was computed by summing up the six Health Belief Model subscales. Hierarchical linear regression was used to test for association between the General Disaster Preparedness Belief score and its associated factors. Results: The General Disaster Preparedness Belief score was positively associated with; higher monthly income, higher occupational status, having experienced any disaster previously and having any emergency/disaster education. Respondents who had any emergency/disaster education had on average an 19.05 higher General Disaster Preparedness Belief score as compared to respondents who had no emergency/disaster education $(\beta=19.05 \pm 4.83$, $p<0.001)$. Furthermore, participants who had experienced any disaster had on average 21.615 higher GDPB score as compared to participants who had never experienced any disaster $(\beta=21.62 \pm 0.32, p<0.001)$. Conclusions: Monthly income, occupational status, previous experiences of disasters and access to emergency/disaster education were important factors associated with General Disaster Preparedness Belief. Interventions aimed at increasing general disaster preparedness should include provision of disaster education and should target individuals with lower socioeconomic status as a priority.
\end{abstract}

Keywords: Disaster, emergency, Health Belief Model, preparedness, sociodemographic characteristics

Correspondence to: Ebru Inal, Emergency and Disaster Management Onsekiz Mart University, Çanakkale, Turkey. E-mail: ebru.inal@hacettepe.edu.tr

Copyright holder Turkish Journal of Public Health

This work is licensed under a Creative Commons Attribution-NonCommercial 4.0 International License. $(\mathrm{cc}) \mathrm{EY}-\mathrm{NC}$ 


\section{Genel afete hazırlık inançları ve ilişkili sosyodemografik özellikler: Yalova Üniversitesi Örneği}

Öz

Amaç: Bu çalışma, kavramsal bir çerçeve olarak Sağlık İnanç Modeli'nin kullanılmasıyla Genel Afetlere Hazırlı İnançları ile ilgili sosyodemografik ve afetlerle ilişkili faktörleri belirlemeyi amaçlamaktadır. Yöntem: Bu araştırma Nisan-Temmuz 2014 yılları arasında Yalova'da yürütülmüştür. Geçerliği kabul edilmiş Sağlık İnanç Modeli'ne dayalı Genel Afetlere Hazırlık İnanç Ölçeği akademik ve idari personelden oluşan 286 kişilik bir çalışma grubuna uygulanmıştır. Genel Afetlere Hazırlık Ölçeği puanı Sağlık İnanç Modeli altölçeklerinin toplanmasıyla elde edilmiştir. Genel Afetlere Hazırlık Ölçeği puanı ve ilişkili faktörler arasındaki ilişki için hiyerarşik linear regresyon kullanılmıştır. Bulgular: Genel Afetlere Hazırlık İnanç puanı daha yüksek aylık gelir, daha yüksek mesleki durum, daha önceki afet deneyimi ve acil durum/afet eğitimi almış olmak ile pozitif olarak ilişkilidir. Daha önce acil durum/afet eğitimi alan katılımcılar daha önce hiç acil durum/afet eğitimi almadığını belirten katılımcılar ilekarşılaştırıldığında ortalama olarak $19.05 \mathrm{kez}$ daha yüksek Genel Afetlere Hazırlık İnanç puanına sahiptir $(\beta=19.05 \pm 4.83, p<0.001)$. Ayrıca, daha önce herhangi bir afet deneyimi olan katılımcılar hiç afet deneyimi olmayan katılımcılar ile karşılaştırıldığında ortalama olarak 21.62 kez daha yüksek Genel Afetlere Hazırlık İnanç puanına sahiptir $(\beta=21.62 \pm 0.32, p<0.001)$. Sonuç: Aylık gelir, mesleki durum, herhangi bir afet deneyimi ve herhangi bir afet eğitimine sahip olma durumu Genel Afetlere Hazırlı İnancı ile ilişkili önemli faktörlerdir. Genel afete hazırlığı artırmayı amaçlayan müdahaleler afet eğitiminin temel ilkesini içermeli ve ilk öncelik olarak daha düşük sosyoekonomik durumda olan kişileri hedeflemelidir.

Anahtar sözcükler: Afet, acil durum, Sağlık İnanç Modeli, hazırlık, sosyodemografik özellikler

\section{Introduction}

Disaster is defined as "A serious disruption of the functioning of society, causing widespread human, material, or environmental losses which exceed the ability of affected society to cope using only its own resources".1 Disasters are natural or man-made emergency events which have negative economic and social consequences for the affected population. ${ }^{2}$ The 20th century had witnessed an increase in disaster losses, and this has continued in an upward trend in the current century. 3, 4 Turkey is prone to natural disasters due to its geological structure. ${ }^{5}$ Turkey has witnessed natural disasters such as earthquake, landslide, and flood. ${ }^{6}$ In Turkey, the earthquake disasters that occurred in
August 17, 1999 in Kocaeli and November 12, 1999 in Duzce were among the most devastating disasters. The 1999 Kocaeli earthquake alone left 17,000 people dead, 200,000 homeless, and resulted in a fiscal cost of some US $\$ 2.2$ billion. ${ }^{5}$

Disaster preparedness is one of the basic components of disaster risk reduction. Effective disaster preparedness (e.g. storing food and water, securing high furniture and water heaters, preparing a household emergency plan) reduces vulnerability, increases mitigation level, enables timely and effective response to a disaster event, shortens the recovery period from a disaster, and increases community resilience. 7, 8 Currently, there is a paucity of studies demonstrating the overall state of individual 
preparedness with regards emergencies/disasters in Turkey. Institutional (mostly hospital-based) and individual studies focusing on specific groups in Turkey can be found in the literatures 9-12 and the reported level of disaster preparedness mentioned in these studies are very low. Disaster preparedness has been shown to be affected by: risk perception, preparedness perception, selfefficacy, community participation, available resources and socio-demographic characteristics. ${ }^{13-18}$

Socio-demographic and disaster related factors associated with disaster preparedness in the literatures include; age, gender, education, level of income, past disaster experience, previous disaster education and property ownership. 18-24

According to previous studies, there are a number of behaviour change models that could be used to examine how perception can influence behaviour modification in relation to health risks. 7, 25-27 The HBM predicts that, "if individuals regard themselves as susceptible to a condition, believe that condition would have potentially serious consequences, believe that a course of action available to them would be beneficial in reducing either their susceptibility to or severity of the condition, and believe the anticipated benefits of taking action outweigh the barriers to (or costs of) action, they are likely to take action that they believe will reduce their risks". ${ }^{25}$ The HBM in addition, also includes a cue to actions variable whereby the individual is spurred to adopt the preventive behavior by internal or external stimuli, for example, exposure to information from the mass media or through discussions with other people. ${ }^{28}$ Later, scholars have suggested that self-efficacy should be incorporated into the HBM as a separate independent variable. ${ }^{29}$ If disaster is perceived as a health threat, then theoretical models such as the Health Belief
Model (HBM) can be used to predict disaster preparedness behavior. In the HBM, disaster preparedness will depend on the following predictors: perceived susceptibility of experiencing a disaster, perceived severity of disaster, benefits of being prepared for a disaster, perceived barriers to being prepared for a disaster, cue to actions for disaster preparedness and individual's belief in their own ability to deal with a disaster. The study utilized the HBM because risk and threat perceptions, which are the main constructs of the HBM are appropriate for assessing individuals' disaster preparedness levels and perceptions. ${ }^{25}$ In Turkey, there is a paucity of studies on disaster preparedness using behavioural theories and this research tries to fill this gap.

This study aimed to investigate socio demographic and disaster related factors associated with General Disaster Preparedness Belief (GDPB) in Yalova University, Turkey using HBM as a theoretical framework.

\section{Methods}

Study Setting: This descriptive study was conducted in the city of Yalova among university staff's in a Turkish University.

Ethics: Permission to conduct the study was obtained from relevant authorities in Yalova (No:47080830-999-334/10.04.2014).Ethical approval was taken from University of Hacettepe Ethical Committee (No:16969557$520 / 12.05 .2014)$. All university staff who participated in the study where given informed consent letters and informed about the purpose of the study. Furthermore, they were also instructed that withdrawal from the study was optional at any time.

Data collection tool: The questionnaire consisted of two parts. The first part had questions covering socio-demographic and disaster related information of participants namely; Age, gender, marital status, 
educational status, number of living children, monthly income, occupational status, house ownership, ever experienced any disaster and past emergency/disaster education. The second part of the questionnaire consisted of a prevalidated GDPB scale instrument based on the HBM. ${ }^{30}$ The instrument consisted of 6 subscales and 31 items as follows; Self efficacy (8 items), Cue to actions (5 items), Perceived susceptibility (6 items), Perceived barriers (6 items), Perceived benefits (3 items) and Perceived severity (3 items) (Appendix 1). GDPB score was the dependent variable. The explanatory variables were: age, gender, marital status, level of education, number of living children, monthly income, occupational status, house ownership, ever experienced any disaster, had any emergency/disaster education.

GDPB score: GDPB score was computed by summing up all the 6 subscales (Self Efficacy + Cue to actions + Perceived susceptibility + Perceived barrier (items were reverse scaled) + Perceived benefits + Perceived severity) such that a higher score represented more positive belief.

The GDPB score was originally conceptualized as a multidimensional instrument, but was determined to be scorable as separate subscales or as a single measure of GDPB. 30 Firstly, we examined Cronbach's coefficient alpha (stratified cronbach alpha 0,93 for GDPB) as a measure of internal consistency. It was high which in turn suggest that the items in each subscales were homogeneous. Also, preliminary analysis showed that the correlations between the GDPB score with the 6 HBM subscales from which it was derived were above 0.50 , and all the correlations were less than 0.01 level of probability. The fact that the correlation coefficients were significant between the 6 HBM subscales and the GDPB score could be taken as evidence for summing up all the 6 subscales and for using the GDPB score. Furthermore, we also examined the fit of a second order factor model. In second order factor modeling, the factor loading of main construct on its subconstructs was performed in order to confirm that the theorized second order construct loaded into the respective subconstructs. The results indicated that the model fit the data. ${ }^{30}$ The second order factor modeling also provided evidence for summing up the 6 subscales.

Study group and data collection: The questionnaires were self-administered and were administered between April and July, 2014. Yalova University had a total of 420 academic staff and 202 administrative staff. Our target sample size was the entire 622 staff. Due to non-response and removal of participants with missing item response, our final sample consisted of a total of 286 academic and administrative staff (46.0\%).

Statistical analysis: For the descriptive statistic of the study participants, continuous variables were reported as means and standard deviations (SDs), if not indicated otherwise. Hierarchical linear regression was performed to estimate the independent effect of sociodemographic and disaster explanatory variables on the outcome variable GDPB score. Model 1 consisted of sociodemographic variable while in Model 2 disaster variables were entered. Statistical analysis was done using the software programs IBM SPSS Statistics version 19.

\section{Results}

Descriptive statistics of participants: The average age of the participants was 32.8 years $( \pm 5.4$ years), more than half of the respondents were males (63.3\%). Almost $53.2 \%$ of participants were currently married. In addition, a higher percentage of respondents had masters and above educational qualification (69.9\%) while about half of respondents had a monthly income of 2.500-2.999 Turkish Lira (TL) 
(\$854-\$1025). Administrative staff made up $30.3 \%$ of the respondents. Approximately $66.0 \%$ of respondents were living in selfowned apartments. In addition, a greater proportion of respondents had ever experienced a disaster (94.8\%) and had not received emergency/disaster education (96.5\%) (Table 1).

Table 1. Socio demographic characteristics and disaster related factors $(n=286)$

\begin{tabular}{|c|c|}
\hline Age (years) $(n=283)$ & n (\%) \\
\hline Range & $25-53$ \\
\hline Mean (SD) & $32.8(5.4)$ \\
\hline \multicolumn{2}{|l|}{ Gender, n (\%) } \\
\hline Female & $105(36.7)$ \\
\hline Male & $181(63.3)$ \\
\hline \multicolumn{2}{|l|}{ Marital status, $n(\%)(n=282)$} \\
\hline Currently Married & $150(53.2)$ \\
\hline Single/ Divorced/Widowed & $132(46.8)$ \\
\hline \multicolumn{2}{|l|}{ Level of education, $n(\%)(n=276)$} \\
\hline Bachelor's degree & $83(30.1)$ \\
\hline Masters and above & $193(69.9)$ \\
\hline \multicolumn{2}{|l|}{ Number of living children $(n=279)$} \\
\hline Range & $0-4$ \\
\hline Mean (SD) & $0.68(0.93)$ \\
\hline \multicolumn{2}{|l|}{ Monthly income (TL), n (\%) (n=283) } \\
\hline $2-2.499$ & $62(21.9)$ \\
\hline 2.5-2.999 & $144(50.9)$ \\
\hline 3.000 and above & $77(27.2)$ \\
\hline \multicolumn{2}{|l|}{ Occupational status, $n(\%)(n=284)$} \\
\hline Teaching assistant & $60(21.1)$ \\
\hline Research assistant & $78(27.5)$ \\
\hline Assistant professor/Associate professor/ Professor. & $60(21.1)$ \\
\hline Administrative staff & $86(30.3)$ \\
\hline
\end{tabular}




\section{Table 1 continue}

House ownership, n (\%) (n=283)

Self-ownership

$186(65.7)$

Renting

Ever experienced any disaster, $n(\%)$

No

Yes

Had any emergency/disaster education, n (\%)

Yes

No

$276(96.5)$

Table 2 presents the distribution of GDPB score and the HBM subscales. "Selfefficacy" subscale has a mean score of 24,69 \pm 6,35 (Min: 9,00, Max: 38,00); “Perceived susceptibility" subscale score has a mean score of 26,57 $\pm 4,04$ (Min:15,00, Max: 35,00) while GDPB has a mean score of $107,03 \pm$ 14,02 (Min:66,00, Max: 145,00) (Table 2).

Table 2. Descriptive characteristics of GDPB score and subscales of HBM

\begin{tabular}{cccccc}
\hline $\begin{array}{c}\text { Scale and } \\
\text { Subscales }\end{array}$ & $\begin{array}{c}\text { Number } \\
\text { of items }\end{array}$ & $\begin{array}{c}\text { Minimum } \\
\text { score }\end{array}$ & Maximum score & Mean & $\begin{array}{c}\text { Standard } \\
\text { Deviation }\end{array}$ \\
\hline GDPB score & 31 & 66,00 & 145,00 & 107,03 & 14,02 \\
$\begin{array}{c}\text { Perceived } \\
\text { Susceptibility }\end{array}$ & 6 & 15,00 & 35,00 & 26,57 & 4,04 \\
$\begin{array}{c}\text { Perceived } \\
\text { Severity }\end{array}$ & 3 & 3,00 & 15,00 & 11,53 & 2,45 \\
$\begin{array}{c}\text { Perceived } \\
\text { Benefits }\end{array}$ & 3 & 4,00 & 15,00 & 11,93 & 1,94 \\
$\begin{array}{c}\text { Perceived } \\
\text { Barriers }\end{array}$ & 6 & 10,00 & 28,00 & 18,58 & 4,07 \\
Cues to & 5 & 6,00 & 25,00 & 13,80 & 4,11 \\
Action & & & 38,00 & & \\
Self-Efficacy & 8 & 9,00 & & 24,69 & 6,35 \\
\hline
\end{tabular}


Factors associated with GDPB score: The first model in the hierarchical regression analysis included "Age, Gender, Marital status, Educational status, Number of living children, Monthly income, Occupational status, and House ownership", in the analysis of variance, $\mathrm{F}$ was significant, meaning the model significantly improved our ability to predict the outcome variable as compared to not fitting the model, the first model explained $\left(R^{2}=0.294\right) 29.4 \%$ of the variance in GDBP score, F $(11,246)=9.394, \mathrm{p}<0.00$. After entry of "ever experienced any disaster" and "had any emergency/disaster education" variables in the second model, the total variance explained totaled up to $42.0 \%$ $\mathrm{F}(13,244)=13.612, \mathrm{p}<0.001$. Ever experienced any disaster and had any emergency/disaster education variables explained an additional $12.5 \%$ of the variance in GDBP score, $\mathrm{R}$ square change $=0$ .125 , $\mathrm{F}$ change $(2,244)=26.218, \mathrm{p}<0.001$.

Factors that were significantly associated with GDPB score after adjustment of socio-demographic and disaster variables (Model 2) were monthly income, occupational status, ever experienced a disaster and received any emergency/disaster education. On the other hand, age, gender, marital status, educational status, number of living children and house ownership were not significantly associated with GDPB score.

Respondents who had a monthly income of 2500 to 2999 Turkish Lira (\$854$\$ 1025$ )had on an average 9.736 higher GDBP score as compared to respondents who had a monthly income of 2000 to 2499 Turkish Lira (\$683-\$854) $(B=9.736 \pm 3.083, \mathrm{p}=0.002)$, also, respondents with monthly income of 3000 TL and above Turkish Lira (\$1025 and above) had on average 14.775 higher GDPB score as compared to respondents with monthly income of 2-2.499TL (\$683-\$854) $(B=14.775 \pm 3.362, \quad \mathrm{p}<0.001) . \quad$ Teaching assistant had on average -8.326 lesser GDBP score as compared to assistant professor/associate professor/professor $(B=-8.326 \pm 2.839, \quad \mathrm{p}=0.004)$. Research assistant had significantly lower GDBP score as compared to assistant professor/associate professor/professor (Model 1), however, this significant was lost after controlling for "Ever experienced any disaster" and "had any emergency/disaster education" in model 2. Participants who had ever experienced any disaster had on average 21.615 higher GDPB score as compared to participants who had never experienced any disaster $(B=21.615 \pm 0.315, \mathrm{p}<0.001)$. Furthermore, having any emergency/disaster education was positively associated with GDPB score. Respondents who had any emergency/disaster education had on an average 19.050 higher GDPB score as compared to respondents who had not had any emergency/disaster education $(B=19.050 \pm 0.206, \mathrm{p}<0.001)$ (Table 3).

\section{Discussion}

The main aim of the study was to use the HBM as a theoretical framework to investigate associations between sociodemographic and disaster related factors with GDPB in Yalova University. The study showed that participants who had higher monthly income, higher occupational status, ever experienced any disaster and having any emergency/disaster education had higher GDPB score. Previous studies had also applied the HBM to study disaster preparedness, for instance, disease outbreak preparedness, 26 and preparedness for climate change and heat waves. ${ }^{27}$ This study focused on general disaster preparedness beliefs, because the most widely employed classification of disaster preparedness has three categories namely; material preparedness, planning activities and knowledge-skills ${ }^{31}$ and this classification is the same for all of disaster types. 
Table 3. Factors associated with GDPB score

\begin{tabular}{|c|c|c|c|c|c|c|}
\hline \multirow[b]{2}{*}{ Characteristics } & \multicolumn{3}{|c|}{ Model 1* } & \multicolumn{3}{|c|}{ Model 2** } \\
\hline & B (SE) & B & P value & B (SE) & $\boldsymbol{\beta}$ & $P$ value \\
\hline Age (years) & $-0.286(0.206)$ & -0.1 .03 & 0.167 & $-0.209(0.189)$ & -0.076 & 0.269 \\
\hline \multicolumn{7}{|l|}{ Gender } \\
\hline Females & Ref & Ref & Ref & Ref & Ref & Ref \\
\hline Male & $1.983(1.878)$ & 0.064 & 0.292 & $1.139(1.715)$ & 0.037 & 0.507 \\
\hline \multicolumn{7}{|l|}{ Marital status } \\
\hline Single/divorced/widowed & Ref & Ref & Ref & Ref & Ref & Ref \\
\hline Currently married & $3.057(2.336)$ & 0.102 & 0.192 & $2.410(2.130)$ & 0.080 & 0.259 \\
\hline \multicolumn{7}{|l|}{ Educational status } \\
\hline Bachelor degree & Ref & Ref & Ref & Ref & Ref & Ref \\
\hline Masters and above & $3.108(3.049)$ & 0.096 & 0.309 & $2.589(2.778)$ & 0.080 & 0.352 \\
\hline Number of living children & $1.251(1.382)$ & 0.078 & 0.366 & $0.524(1.263)$ & 0.033 & 0.679 \\
\hline \multicolumn{7}{|l|}{ Monthly income } \\
\hline $2,000-2,499$ TL $(\$ 683-\$ 854)$ & Ref & Ref & Ref & Ref & Ref & Ref \\
\hline 2,500-2,999 TL (\$854-\$1025) & $12.174(3.355)$ & 0.405 & $<0.001$ & $9.736(3.083)$ & 0.324 & 0.002 \\
\hline $3,000 \mathrm{TL}$ and above ( $\$ 1025$ and above) & $17.479(3.655)$ & 0.513 & $<0.001$ & $14.775(3.362)$ & 0.434 & $<0.001$ \\
\hline
\end{tabular}


Table 3 continue

\section{Occupational status}

Assistant professor/Associate professor/ Professor

$\begin{array}{llllll}\text { Ref } & \text { Ref } & \text { Ref } & \text { Ref } & \text { Ref } & \text { Ref } \\ -10.938(3.048) & -0.303 & <0.001 & -8.326(2.839) & -0.230 & 0.004 \\ -7.964(3.438) & -0.243 & 0.021 & -5.661(3.177) & -0.173 & 0.076 \\ -0.222(3.727) & -0.007 & 0.953 & 2.141(3.441) & 0.065 & 0.534 \\ & & & & & \\ \text { Ref } & \text { Ref } & \text { Ref } & \text { Ref } & \text { Ref } & \text { Ref } \\ -1.446(1.780) & -0.046 & 0.417 & -1.219(1.624) & -0.039 & 0.454\end{array}$

Teaching assistant

Ref

Ref

Ref

Ref

Ref

Yes

Ref

$21.615(3.528)$

0.315

$<0.001$

\section{Had any emergency/disaster education}

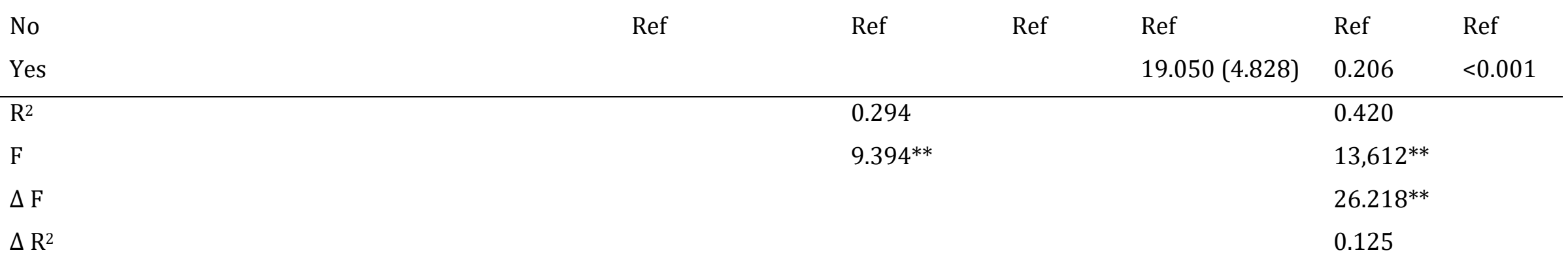

Notes: $B=$ Unstandardized coefficient, $S E=$ Standard Error, $\beta=$ Standardized coefficient, Model 1= Sociodemographic factors, Model $2=$ Model $1+$ Disaster variable, $*^{* *}=\mathrm{p}<0.001$

* Model 1 is adjusted for Age, Gender, Marital status, Educational status, Number of living children, Monthly income, Occupational status, and House ownership.

** Model 2 is adjusted for Age, Gender, Marital status, Educational status, Number of living children, Monthly income, Occupational status, House ownership, ever experienced any disaster and Had any emergency/disaster education. 
We found statistically significant associations between GDPB score and the following variables; monthly income, occupational status, ever experienced any disaster and having any emergency/disaster education.

Monthly income was an important determinant of GDPB score. According to our findings GDPB score was positively associated with higher monthly income. In consonance, Najafi et al also found that people with higher income were more prepared for disasters as compared to people with low income. ${ }^{18}$ This finding could be explained by the fact that people with higher income are expected to have enough resources for performing preparedness behaviors such as living in areas less prone to disasters, and having qualified properties. 32,33 A previous study associated belonging to the lower income group with limited resources for taking preparedness and response actions. ${ }^{33}$

Occupational status was another significant predictor of GDBP in our study setting. GDPB score was lower among teaching assistants as compared to assistant professors/associate professors/professors. This finding might be related to accessibility to disaster preparedness information and ability to carry out disaster preparedness activity. The lower salaries received by the first group and having less experience in disasters due to their younger age may be another explanatory possibility. Studies done in Iran ${ }^{18}$ and in the USA ${ }^{34}$ also showed an association between disaster preparedness behavior and occupational status.

Previous disaster experience emerged as a significant factor associated with GDPB score. Respondents who had previous disaster experience had higher GDPB score as compared to those who had not. Literature with regards to prior disaster experience and disaster preparedness showed mixed results. Some studies showed that past disaster experience was associated with an inclination to undertake preparedness activities thereafter 23, 24 whereas others showed that past disaster experience has little or no bearing on preparedness behaviors for the future. ${ }^{35,} 36$ In a study done in New York City, the intensity of exposure to the September 2001 World Trade Center terrorism attack and lifetime exposure to traumatic events were associated with greater personal preparedness. ${ }^{37}$

In the current study, having a previous emergency/disaster education was significantly associated with increased GDPB score, this result was not a surprising finding as previous emergency/disaster education is expected to increase an individual's preparedness by enhancing cognitive and risk evaluation skills. Our study finding was in consonance with a previous study done in Turkey. 38

We observed that age was not significantly associated with disaster preparedness, our findings with regard to age is in consonance with a study done in Tehran. These authors also found that age was not significantly associated with disaster preparedness. ${ }^{18}$ Gender in addition was also not a significant predictor of disaster preparedness in our study, however, some studies strongly state that women are less prepared for disasters as compared to men, while other studies reject this hypothesis. ${ }^{20}$, 39, 40 Disaster preparedness among men and women may differ due to their societal differences in role and responsibilities as well as inequality in terms of decisionmaking power.

Educational status was also not a significant finding in our study, though, studies in the area of disaster preparedness and education have found significant positive correlations between the two. 41, 42 In addition, being married and having living children were also not significant predictors 
of GDPB score in our study, however, a previous study showed that having more household member could contribute to how household heads prepare for a disaster. 18, 43 Furthermore, our study did not find a significant association between house ownership and GDPB score, on the other hand, a previous study showed that home owners seem to be more prepared for disaster than those who rent the place. 22

The study has some limitations. The study sample size was restricted to a group comprising of individuals who were at a higher level of education as compared to the general population. Future study could focus on a much larger sample involving different study groups. In addition, our target sample size was the whole university's staff, however, the response rate was low, which resulted in a reduced sample size and power. The results of the study may also be skewed towards respondents who chose to participate, in addition, our findings may not be generalizable to the wider community, because the surveyed respondents may differ in important ways from the general population. It is also worth noting that the data collection instrument was non-specific in terms of hazard/s as the study aim was to assess general disaster preparedness beliefs.

\section{Conclusions}

This study attested that general disaster preparedness in Yalova University was associated with monthly income, occupational status, ever experienced a disaster and having any emergency/disaster education. These indicators could be the focus of further studies with regard to general disaster preparedness. Interventions aimed at increasing general disaster preparedness should include provision of disaster education and should target individual with lower socioeconomic status as a priority. Therefore, the effective educational programs based on HBM should be designed and implemented with emphasis on changing attitude toward to promote general disaster preparedness.

Conflict of Interest: There is no conflict of interest in this study.

Financial support: The authors received nil financial support for this study.

Acknowledgements: This study was presented as oral presentation in 2 . International 20. National Public Health Congress 2018.

Authors' contributions: Ebru Inal (EI) and K. Hakan Altintas (KHA) designed the study, EI collected the data, EI wrote the manuscript. Nuri Doğan (ND) and EI made statistical analyses. KHA and ND made contributions to the interpretation of results and revised the manuscript. All the authors read and approved the final version.

\section{References}

1. United Nations, Department of Humanitarian Affairs. Internationally Agreed Glossary of Basic Terms Related to Disaster Management. (DNA/93/36). United Nations. Geneva, 1992.

2. Donahue A, Joyce P. A Framework for Analyzing Emergency Management with an Application to Federal Budgeting. Public Administration Review 2001; 61(6):728-740.

3. Guha-Sapir D, Hoyois Ph, Below R. Annual Disaster Statistical Review 2013: The numbers and trends, Centre for Research on the Epidemiology of Disasters CRED, Institute of Health and Society (IRSS), 2014.

4. International Federation of Red Cross and Red Crescent Societies (IFRC). World Disaster Report: Focus on Technology and the Future Humanitarian Action, Geneva, 2013. 
5. Ersoy S, Kocak A. Disasters and Earthquake Preparedness of Children and Schools in Istanbul, Turkey. Geomatics, Natural Hazards and Risks 2016; 7(4);1307-1336.

6. Gokce 0, Ozden S, Demir A. The Statistical and Spatial Distribution of Disasters in Turkey Disaster Information Inventory Ankara. Turkish Ministry of Public Works and Settlement, Disaster Research and Assessment Department, 2008, p. 118.

7. Ejeta L.T, Ardalan A, Paton D. Application of Behavioral Theories to Disaster and Emergency Health Preparedness: A Systematic Review. 2015. PLOS Currents Disasters Edition 1.doi:10.1371/currents.dis.31a8995ced3 $21301466 \mathrm{db} 400 \mathrm{f} 1357829$.

8. Gregory R.C, Philip D.A, Erik A.D.H, et al. Disaster Medicine. U.S.A.: Mosby Elsevier, 2006, pp.29.

9. Özşahin E, Kaymaz KÇ. Afet Kültürünün Değerlendirilmesine Bir Örnek: Antakya Şehri [Bildiri]. Türkiye Deprem Mühendisliği ve Sismoloji Konferansı 2527 Eylül 2013 -MKÜ-HATAY. Erişim Tarihi: 21.07.2018. http://www.tdmd.org.tr/TR/Genel/pdf/ TDMSK039.pdf

10. Dedeoğlu N. Afetlere Niye Hep Hazırlıksız Yakalanıyoruz? Bir Antalya Araştırması [Bildiri]. Deprem Sempozyumu Kocaeli. 23-25 Mart 2005. 1503-05. Erişim Tarihi: 21.07.2017. http://kocaeli2007.kocaeli.edu.tr/kocaeli 2005/deprem_sempozyumu_kocaeli_200 5/8_deprem_ve_insad_52_afet_yonetimi_a fete_hazirlik_ve_afet_bilinci/afetlere_niye_ hep_hazirliksiz_yakalaniyoruz_bir_antalya _arastirmasi.pdf

11. Vatan F, Salur D. Yönetici Hemşirelerin Hastanelerdeki Deprem Afet Planları Konusundaki Görüşlerinin İncelenmesi.
Maltepe Üniversitesi Hemşirelik Bilim ve Sanat Dergisi.2010; 3(1): 32-44.

12. Kokcu A, Kuguoglu S, Ergun A. An Assessment of Emergency and Disaster Preparedness in High Schools in IstanbulTurkey. Health MED. 2012; 6(8): 26202634.

13. Armas I, Avram E. Patterns and Trends in the Perception of Seismic Risk. Case study: Bucharest Municipality/Romania. Natural Hazards 2008;44(1):147-61.

14. Mulilis J.P, Duval T.S. Negative Threat Appeals and Earthquake Preparedness: A Person Relative to Event (PrE) Model of Coping with Threat. Journal of Applied Social Psychology 1995;25(15):1319-39.

15. McClure J, Walkey F, Allen M. When Earthquake Damage is Seen As Preventable: Attributions, locus of control and attitudes to risk. Applied Psychology 1999;48(2): 239-56.

16. Paton D. Disaster resilience: Integrating Individual, Community, Institutional and Environmental Perspectives. Disaster Resilience: An integrated approach. 2006; 306- 19.

17. Mileti D.S, Darlington J. Societal Response to Revised Earthquake Probabilities in the San Francisco Bay Area. International Journal of Mass Emergencies and Disasters 1995;13(2):119-45.

18. Najafi M, Ardalan A, Akbarisari A., et al. Demographic Determinants of Disaster Preparedness Behaviors Amongst Tehran Inhabitants, Iran. 2015. PLOS Currents Disasters.Edition1,doi:10.1371/currents. dis.976b0ab9c9d9941cbbae3775a6c5fbe 6

19. Bourque L.B, Siegel J.M, Kano M, Wood M.M. Morbidity and Mortality Associated with Disasters, in: Handbook of Disaster Research, Springer science, New York, 2006;97-112. 
20. Austin D.W. Surviving the Next Disaster: Assessing The Preparedness of Community Based Organizations: University of Colorado at Boulder, 2010.

21. Kim Y, Kang J. Communication, Neighbourhood Belonging and Household Hurricane Preparedness. Disasters, 2010;34, 470-488.

22. Baker E. Household Preparedness for The Aftermath of Hurricanes in Florida. Appl. Geogr., 2011; 31, 46-52.

23. Tekeli-Yesil S, Dedeoglu N, Tanner M, et al. Individual Preparedness and Mitigation Actions for a Predicted Earthquake in Istanbul. Disasters 2010;34 (4): 910-930.

24. Lindell M.K, Prater C.S. Risk Area Residents' Perceptions and Adoption of Seismic Hazard Adjustments. Journal of Applied Social Psychology 2002; 32(11): 2377-2392.

25. Glanz K, Rimer B.K, Viswanath K, (eds). Health Behavior and Health Education: Theory, Research, and Practice. John Wiley \& Sons, 2008.

26. Teitler-Regev S, Shahrabani S, Benzion U. Factors Affecting Intention Among Students to Be Vaccinated Against A/H1N1 Influenza: A Health Belief Model Approach. Advances in Preventive Medicine Article, 2011, ID 353207, 8 pages

http://dx.doi.org/10.4061/2011/353207.

27. Akompab D.K, Bi P, Williams S, Grant J, Walker I.A, Augoustinos M. Heat Waves and Climate Change: Applying the Health Belief Model to Identify Predictors of Risk Perception and Adaptive Behaviors in Adelaide, Australia. International Journal of Environmental Research and Public Health 2013; 10(6): 2164-2184.

28. Rosenstock I. M. Why People Use Health Services. The Milbank Memorial Fund Quarterly 1966; 44 (3):94-127.
29. Rosenstock I. M, Strecher V. J, Becker M. H. Social Learning Theory and the Health Belief Model. Health Education Quarterly 1988;15(2): 175-183.

30. Inal E, Altintas K. H, \& Dogan N. The Development of a General Disaster Preparedness Belief Scale Using the Health Belief Model as a Theoretical Framework. International Journal of Assessment Tools in Education, 2018; 5(1), 146-158.

31. Sakiroglu M. Variables Related to Earthquake Preparedness Behavior. The Thesis of the Graduate School of Social Sciences of Middle East Technical University, Ankara, 2015.

32. King D. You're on Your Own: Community Vulnerability and the Need for Awareness and Education for Predictable Natural dDisasters. Journal of Contingencies and Crisis Management 2000; 8(4):223-228.

33. Bourque L.B, Mileti D.S, Kano M, Wood M.M. Who Prepares for Terrorism? Environment and Behavior 2012; 44(3): 374-409.

34. Sherman M, Peyrot M, Magda L, Gershon R. Modeling Pre-evacuation Delay by Evacuees in World Trade Center Towers 1 and 2 on September 11, 2001: A revisit using regression analysis. Fire Safety Journal 2011;46(7): 414-24.

35. Harvatt J, Petts J, Chilvers J. Understanding Householder Responses to Natural Hazards: Flooding and Sea-level Rise Comparisons. Journal of Risk Research 2011; 14(1): 63-83.

36. Basolo V, Steinberg L.J, Burby R.J, et al. The Effects of Confidence in Government and Information on Perceived and Actual Preparedness in Disasters. Environment and Behavior 2008;41(3): 338-362.

37. Boscarino J.A, Adams E.R, Figley R.C, Galea S, Foa B.E. Fear of Terrorism and Preparedness in New York City 2 years 
After the Attacks: Implications for Disaster Planning and Research. J Public Health Manag Pract. 2006;12 (6): 05-513.

38. Inal E, Kocagoz S, Turan M. Basic Disaster Consciousness and Preparation Levels, Tr J Emerg Med, 2010;12 (1): 1519.

39. Wood M. M, Kano M, Mileti D. S, \& Bourque L. B. Reconceptualizing Household Disaster Readiness: The "Get Ready" Pyramid. Journal of Emergency Management, 2009;7(1):25-37.

40. Fothergill A, Maestas E, Darlington J. Race, Ethnicity, and Disasters in the United States: A Review of Literature. Disasters 2011; 23: 156-173.
41. Council for Excellence in Government (CEG). Introducing the Public Readiness Index: A Survey Based Tool to Measure the Preparedness of Individuals, Families and Communities. Washington, DC: CEG, 2006.

42. Peacock G, Morrow H, Girard C. Ethnic and Racial Inequities in Hurricane Damage and Insurance Settlements, Routledge, New York, 1999;171-190.

43. Kirschenbaum A. Families and Disaster Behavior: A Reassessment of Family Preparedness. International Journal of Mass Emergencies and Disasters. 2006; 24(1):111. 
Table Appendix 1. General Disaster Preparedness Belief items

\begin{tabular}{|c|c|}
\hline Efficacy 1 & $\begin{array}{l}\text { I can not create an emergency /disasters evacuation plan with the people who } \\
\text { live around my neighbourhood (R) }\end{array}$ \\
\hline Efficacy2 & I can do basic first aid \\
\hline Efficacy3 & I can specify the hazards which can cause a fire \\
\hline Efficacy 4 & I can not conduct search and rescue to action even at the basic level (R) \\
\hline Efficacy5 & I can fix the furnitures that need to be fixed at home \\
\hline Efficacy 6 & $\begin{array}{l}\text { After an emergency situation/disaster, I can access the necessary services } \\
\text { needed for psychological support. }\end{array}$ \\
\hline Efficacy7 & I can not use a fire extinguisher (R) \\
\hline Efficacy8 & $\begin{array}{l}\text { I can determine a safe place at home/in the building to stay during an } \\
\text { earthquake }\end{array}$ \\
\hline Cue to action 1 & $\begin{array}{l}\text { The policies on emergency situation/disaster encourage me to be prepared } \\
\text { for emergency situations/disasters }\end{array}$ \\
\hline Cue to action2 & $\begin{array}{l}\text { My friends enlighten me about the necessity of making individual } \\
\text { preparations for emergency situations/disasters }\end{array}$ \\
\hline Cue to action3 & Booklets, newspapers, brochures do not inform me enough (R) \\
\hline Cue to action 4 & $\begin{array}{l}\text { The people to whose opinion I pay much importance to guide me on the } \\
\text { subject of emergency /disaster preparedness }\end{array}$ \\
\hline Cue to action 5 & $\begin{array}{l}\text { My family members do not inform me about the necessity of making } \\
\text { individual preparations for emergency situations/disasters (R) }\end{array}$ \\
\hline Susceptability1 & $\begin{array}{l}\text { I do not attach importance to preparing emergency/disaster kit for emergency } \\
\text { situations/disasters preparation }(\mathrm{R})\end{array}$ \\
\hline Susceptability 2 & $\begin{array}{l}\text { I take into consideration that I may experience an emergency situation/a } \\
\text { disaster at some point in my life }\end{array}$ \\
\hline Susceptability3 & $\begin{array}{l}\text { It is important for me to enhance building durability in the case of emergency } \\
\text { situations/disasters preparation }\end{array}$ \\
\hline Susceptability 4 & $\begin{array}{l}\text { My possibility of experiencing an emergency situation/a disaster is very high } \\
\text { in the next couple of years. }\end{array}$ \\
\hline Susceptability5 & I find it unnecessary to fix the furniture that need to be fixed at home(R) \\
\hline Susceptability6 & $\begin{array}{l}\text { I do not talk about necessary emergency contact numbers during emergency } \\
\text { situations/disasters in my neighbourhood (R) }\end{array}$ \\
\hline Barrier1 & $\begin{array}{l}\text { It takes too much time of mine to make individual preparations for emergency } \\
\text { situations/disasters (R) }\end{array}$ \\
\hline Barrier2 & $\begin{array}{l}\text { I have responsibilities more important than making preparations for } \\
\text { emergency situations/disasters (R) }\end{array}$ \\
\hline Barrier3 & $\begin{array}{l}\text { I do not have enough information on individual emergency/disaster } \\
\text { preparedness. (R) }\end{array}$ \\
\hline Barrier4 & $\begin{array}{l}\text { I do not have enough money to make preparations for emergency } \\
\text { situations/disasters(R) }\end{array}$ \\
\hline Barrier5 & $\begin{array}{l}\text { If it is my destiny to die as a result of emergency situations/disasters, I will } \\
\text { die. (R) }\end{array}$ \\
\hline Barrier6 & I find it difficult to understand the family disaster plan (R) \\
\hline Benefit1 & $\begin{array}{l}\text { My making individual preparations for emergency situations/disasters will } \\
\text { also save my family members }\end{array}$ \\
\hline Benefit2 & $\begin{array}{l}\text { Making preparations for emergency situations/disasters is helpful for my } \\
\text { needs during emergency situations/disasters }\end{array}$ \\
\hline Benefit3 & Making individual preparations for emergency situations/disasters may \\
\hline
\end{tabular}


decrease the risk of death after emergency situations/disasters

Severity1 An emergency situation/a disaster experience would not change my life (R)

Severity2 I am afraid of dying as a result of emergency situations/disasters

Severity3 The idea of disasters scares me

Note: $\mathrm{R}=$ Reversed scaled

Table Appendix 2. General Disaster Preparedness Belief items (Turkish Version)

eff1 Mahallemde yaşayanlarla birlikte Acil durumlar/Afetler ile ilgili tahliye planı oluşturamam.

eff2 Temel ilk yardım uygulayabilirim.

eff3 Yangın çıkmasına neden olacak tehlikeleri belirleyebilirim.

eff4 Basit düzeyde olsa dahi arama-kurtarma yapamam.

eff5 Evde sabitlenmesi gereken eşyaları sabitleyebilirim.

eff6 Acil durum/afet sonrası ihtiyacım olursa psikolojik destek almak için gerekli hizmete erişebilirim.

eff7 Yangın söndürme cihazını kullanamam.

eff8 Depremden korunmak için yaşadığım evde/binada güvenli yer belirleyebilirim.

cue1 Acil durum/Afet konusundaki politikalar beni Acil Durumlar/Afetler konusunda hazırlıklı olmaya teşvik ederler.

cue2 Arkadaşlarım Acil durumlara/Afetlere bireysel hazırlık yapmanın gerekliliği konusunda beni aydınlatırlar.

cue3 Kitapçıklar, gazeteler, broşürler beni yeterince bilgilendirmezler.

cue4 Fikirlerine önem verdiğim insanlar acil durumlara/afetlere hazırlıklı olma konusunda beni yönlendirirler.

cue5 Aile üyelerim Acil durumlara/Afetlere bireysel hazırlık yapmanın gerekliliği konusunda beni bilgilendirmezler.

sus1 Acil durumlara/Afetlere hazırlıkta acil durum/afet çantası hazırlamayı önemsemem.

sus2 Yaşamımın herhangi bir döneminde Acil durum/Afet yaşayacağımı göz önünde bulundururum.

sus3 Acil durumlara/Afetlere hazırlıkta bina dayanıklılığını artırmak benim için önemlidir.

sus4 Önümüzdeki birkaç yıl içinde Acil durum/Afet yaşama ihtimalim çok yüksektir.

sus5 Evdeki sabitlenebilecek eşyaları sabitlemeyi gereksiz buluyorum.

sus6 Yakın çevrem ile acil durumlarda/afetlerde gerekli acil iletişim numaraları hakkında konuşurum.

bar1 Acil durumlara/Afetlere bireysel hazırlık yapmak çok fazla zamanımı alır.

bar2 Acil durumlara/Afetlere hazırlık yapmaktan çok daha önemli sorumluluklarım var.

bar3 Acil durumlara/Afetlere bireysel hazırlık yapmak için yeterli bilgim yok.

bar4 Acil durumlara/Afetlere hazırlık yapmak için yeterli param yok.

bar5 Kaderimde Acil durumlarda/Afetlerde ölmek varsa ölürüm

bar6 Aile için afet planının anlaşılması zordur.

ben1 Acil durumlara/Afetlere bireysel hazırlık yapmam aile bireylerimi de koruyacaktır.

ben2 Acil durumlara/Afetlere hazırlık yapmak acil durumlarda/afetlerde ihtiyaçlarıma karşılık verecektir.

ben3 Acil durumlara/Afetlere bireysel hazırlık yapmak acil durumlar/afetler sonrası ölüm riskini azaltabilir.

sev1 Acil durum/Afet yaşarsam hayatımda hiçbir şey değişmeyecek.

sev2 Acil durumlar/Afetler sonucunda ölmekten korkarım.

sev3 Acil durum/Afet yașama ihtimalini düșünmek beni korkutur. 
